\title{
Switchgrass (Panicum virgatum L.) Intraspecific Variation and Thermotolerance Classification Using in Vitro Seed Germination Assay
}

\author{
Ramdeo Seepaul ${ }^{1}$, Bisoondat Macoon ${ }^{2}$, K. Raja Reddy ${ }^{1 *}$, Brian Baldwin ${ }^{1}$ \\ ${ }^{1}$ Department of Plant and Soil Sciences, Mississippi State University, Mississippi, USA; ${ }^{2}$ Central Mississippi Research and Extension \\ Center, Raymond, Mississippi, USA. \\ *Email: krreddy@pss.msstate.edu \\ Received March $4^{\text {th }}, 2011$; revised May $9^{\text {th }}, 2011$; accepted May $17^{\text {th }}, 2011$.
}

\begin{abstract}
Cardinal temperatures for plant processes have been used for thermotolerance screening of genotypes, geoclimatic adaptability determination and phenological prediction. Current simulation models for switchgrass (Panicum virgatum L.) utilize single cardinal temperatures across genotypes for both vegetative and reproductive processes although intra-specific variation exists among genotypes. An experiment was conducted to estimate the cardinal temperatures for seed germination of 14 diverse switchgrass genotypes and to classify genotypes for temperature tolerance. Stratified seeds of each genotype were germinated at eight constant temperatures from $10^{\circ} \mathrm{C}$ to $45^{\circ} \mathrm{C}$ under a constant light intensity of $35 \mu \mathrm{mol} \cdot \mathrm{m}^{-2} \cdot \mathrm{s}^{-1}$ for $12 \mathrm{~h} \cdot \mathrm{d}^{-1}$. Germination was recorded at 6-h intervals in all treatments. Maximum seed germination (MSG) and germination rate (GR), estimated by fitting Sigmoidal function to germination-time series data, varied among genotypes. Quadratic and bilinear models best described the MSG and GR responses to temperature, respectively. The mean cardinal temperatures, $T_{\min }, T_{\text {opt }}$, and $T_{\max }$, were 8.1, 26.6, and $45.1^{\circ} \mathrm{C}$ for MSG and 11.1, 33.1, and $46.0^{\circ} \mathrm{C}$ for $G R$, respectively. Cardinal temperatures for MSG and GR; however, varied significantly among genotypes. Genotypes were classified as sensitive ('Cave-in-rock', 'Dacotah', 'Expresso', 'Forestburg', 'Kanlow', 'Sunburst', 'Trailblazer' and 'Tusca'), intermediate ('Alamo', 'Blackwell', 'Carthage', 'Shawnee', and 'Shelter') and tolerant ('Summer') to high temperature based on cumulative temperature response index (CTRI) estimated by summing individual response indices estimated from the MSG and GR cardinal temperatures. Similarly, genotypes were also classified as sensitive (Alamo, Blackwell, Carthage, Dacotah, Shawnee, Shelter and Summer), moderately sensitive (Cave-in-rock, Forestburg, Kanlow, Sunburst, and Tusca), moderately tolerant (Trailblazer), and tolerant (Expresso) to low temperatures. The cardinal temperature estimates would be useful to improve switchgrass models for field applications. Additionally, the identified cold-and heat-tolerant genotypes can be selected for niche environments and in switchgrass breeding programs to develop new genotypes for low and high temperature environments.
\end{abstract}

Keywords: Switchgrass, Cardinal Temperature, Temperature Tolerance, Germination, Genotype Variability, Response Index, Screening, Genotype Classification

\section{Introduction}

The adoption of a biomass feedstock crop for a niche environment is favoured on the species ability to grow and sustain under a wide range of growing conditions and its ability to produce high yields and quality biomass. From an agronomic perspective, the crop should also be able to establish rapidly and uniformly under existing conditions to escape weed competition and late-season water unavailability [1]. Establishment of warm-season feedstock grasses has been limited due to slow germina- tion and low seedling vigor [2,3], particularly in the first year after seeding, presenting a major problem in the improvement of existing stands, or in establishing new stands. Slight or moderate successes of native grasses establishment can be attributed to seed dormancy and delayed germination [4]. Seeding feedstock fields requires knowledge of many parameters, including optimum temperature and moisture conditions for rapid germination and establishment $[5,6]$.

Switchgrass (Panicum virgatum L.), a warm-season, native $\mathrm{C}_{4}$ bunch grass species was identified as a poten- 
tial and model lignocellulosic biofuel feedstock by the U.S. Department of Energy's Bioenergy Feedstock Development Program [7]. It is a highly diverse species with significant genetic [8] and phenotypic variation resulting from gene migration, random genetic drift, mutation, natural selection [9] combined with environment dissimilarity due to latitude, altitude, soil type, and precipitation [10].

Temperature is a major environmental factor influencing seed germination capacity and rate and seedling vigor [3] through three distinct processes; it effects on seed deterioration (seed aging), dormancy loss, and on the germination process itself [11]. Extreme temperatures are the single most important factor delimiting the distribution, adaptability, and yield potential of plants. Suband supra-optimal soil temperatures at seeding can affect both the germination rate and maximum seed germination; therefore breeding for seed temperature tolerance may be necessary for adequate and uniform crop establishment.

Determining temperature effects on seed germination using mathematical functions may be useful in evaluating germination characteristics or establishment potential among genotypes or species [12]. Final seed germination percentage and germination rate are both considered sensitive indicators of seed vigor [13]. Germination can be characterized by three cardinal temperatures (minimum, $\mathrm{T}_{\min }$; maximum, $\mathrm{T}_{\max }$ and optimum, $\mathrm{T}_{\mathrm{opt}}$ ) that determine the range of temperatures across which germination can occur. Previous studies that reported effects of temperature on switchgrass germination capacity and rate did not quantify the cardinal temperatures for diverse switchgrass genotypes. Switchgrass germinates slowly when the temperature is below $15.5^{\circ} \mathrm{C}$ with maximum germination occurring within $3 \mathrm{~d}$ of imbibition at $29.5^{\circ} \mathrm{C}$ [14]. Minimum temperature for switchgrass germination is $10.3^{\circ} \mathrm{C}$ and optimum temperature occurring between $25^{\circ} \mathrm{C}$ and $30^{\circ} \mathrm{C}$ [15]. Minimum temperatures are critical for accurate phenological predictions because minute differences in temperatures can cause considerable differences in germination time. Current switchgrass models that simulate switchgrass phenology use blanket minimum temperatures that range from $10^{\circ} \mathrm{C}$ to $12^{\circ} \mathrm{C}$ [16-18], although it is suspected that there is intra-species variation.

The interest in switchgrass as a feedstock has fostered development and selection of a wide number of genotypes, which must be screened for various abiotic stress tolerances prior to release. Current screening methods are restricted to field performance and visual evaluations which may mask a genotype's true potential or tolerance capacity due to unpredictable moisture and fluctuating temperatures in the field. Field screening for temperature tolerance is tedious, inconsistent, and seasonally limited; therefore the need for simple, rapid, and reliable techniques to identify sources of tolerance and for evaluating a large number of breeding materials in controlled environments is required [19]. Screening for abiotic stress tolerance has been achieved using biochemical and physiological parameters at the germination, emergence, vegetative, and reproductive stages. In vitro seed-based screening can provide insights into genotypic environmental adaptability and tolerance capacity prior to field evaluations. Studies related to temperature tolerance screening in switchgrass; however, are limited in general and no reported studies using seed-based parameters have been found. Seed-based parameters, in particular, germination capacity and rate have been used successfully to screen several species and genotypes for various abiotic stress factors including drought [20,21], saline [22,23], flooding/water logging [24], chilling [25,26], and heat tolerance $[27,28]$ in other species. The temperature tolerance capacity of different genotypes may be determined by relative ranking using single value indices, percentiles and quartiles relative to control studies and cumulative indices, groupings based on statistical separation of means [28-30] or quantitative relationships determined by principal component analysis [31-33].

The objectives of this study were to 1) quantify the effects of temperature on seed germination capacity and rate, 2) determine the cardinal temperatures for seed germination capacity and rate, and 3) classify genotypes for temperature tolerance using cumulative temperature response index concept. The seed germination and temperature dependent functional algorithms developed from these data are a prerequisite for modeling the germination of switchgrass genotypes adapted to different climatic zones.

\section{Materials and Methods}

\subsection{Seed Material}

Seeds of 14 switchgrass genotypes, representative of northern and southern, upland and lowland ecotypes, were evaluated in this experiment (Table 1). For nine cultivars, seeds were collected from the plants grown during the 2006-2007 growing season at Mississippi State, MS $\left(33^{\circ} 28^{\prime} \mathrm{N}, 88^{\circ} 47^{\prime} \mathrm{W}\right)$ and stored at $10^{\circ} \mathrm{C}$ and $40 \%$ RH. Seeds of Blackwell, Carthage, Cave-in-Rock, Shawnee, and Shelter were obtained from the Ernst Seed Company (Meadville, PA) from the 2006-2007 growing season and stored at similar conditions. All seeds were kept in cold storage to maintain seed quality prior to testing. Seeds were homogenously mixed and 100 seed per experimental unit for germination testing were counted 
Table 1. Ploidy level, ecotype, latitude, origin and plant hardiness zone (PHZ) of switchgrass genotypes.

\begin{tabular}{|c|c|c|c|c|c|c|c|}
\hline Genotype & $\begin{array}{l}\text { Ploidy } \\
\text { Level }\end{array}$ & Ecotype & Latitude & Origin & PHZ & Remarks & Reference \\
\hline Alamo & $\mathrm{T}$ & lowland & & southern TX & 6 & Selected for biomass & \\
\hline Blackwell & $\mathrm{H}$ & upland & $\mathrm{S}$ & Blackwell, OK & $5 \mathrm{a}$ & & Riley and Vogel (1982) \\
\hline Carthage & $\mathrm{O}$ & upland & & southern IL & & & \\
\hline Cave-in-Rock & $\mathrm{H}$ & $\begin{array}{l}\text { lowland/ } \\
\text { upland }\end{array}$ & $\mathrm{S}$ & Cave-in-Rock, IL & $4 \mathrm{~b}$ & & Riley and Vogel (1982) \\
\hline Dacotah & $\mathrm{T}$ & upland & & North Dakota & $4 a$ & $\begin{array}{c}\text { Early maturity, winter } \\
\text { hardy, high stand density, } \\
\text { persistent }\end{array}$ & Barker et al. (1990) \\
\hline Expresso & & lowland & & Mississippi & & $\begin{array}{l}\text { Selected for improved } \\
\text { germination }\end{array}$ & \\
\hline Forestburg & $\mathrm{T}$ & upland & $\mathrm{N}$ & Forestburg, SD & $3 b-4 b$ & $\begin{array}{c}\text { Early, maturity, excellent } \\
\text { winter hardiness and } \\
\text { persistence, good seed } \\
\text { potential }\end{array}$ & Barker et al. (1988) \\
\hline Kanlow & $\mathrm{T}$ & lowland & $\mathrm{N}$ & Wetumka, OK & 5 & & \\
\hline Shawnee & $\mathrm{O}$ & upland & $\mathrm{S}$ & Cave-in-Rock, IL & & $\begin{array}{l}\text { High forage yield and } \\
\text { quality }\end{array}$ & Vogel et al. (1996) \\
\hline Shelter & $\mathrm{H}$ & $\begin{array}{l}\text { lowland/ } \\
\text { upland }\end{array}$ & $\mathrm{N}$ & St. Mary's, WV & 4 & & Wullschleger et al. (1996) \\
\hline Summer & $\mathrm{T}$ & upland & & Southern NE & 4 & & \\
\hline Sunburst & $\mathrm{H}$ & upland & $\mathrm{N}$ & South Dakota & & $\begin{array}{l}\text { Winter hardy, leafy, } \\
\text { heavy-seeded, superior } \\
\text { seedling vigor }\end{array}$ & $\begin{array}{c}\text { Boe and Ross (1998); } \\
\text { Wullschleger et al. (1996) }\end{array}$ \\
\hline Trailblazer & $\mathrm{H}$ & upland & $\mathrm{N}$ & Nebraska & & $\begin{array}{l}\text { High forage quality, high } \\
\text { IVDMD }\end{array}$ & Vogel et al. (1991) \\
\hline Tusca & & lowland & & Mississippi & & $\begin{array}{l}\text { Selected for herbicide } \\
\text { tolerance from Alamo }\end{array}$ & \\
\hline
\end{tabular}

Genotypes are classified based on ploidy level $(\mathrm{T}=$ tetraploid, $\mathrm{H}=$ hexaploid, and $\mathrm{O}=$ octaploid $)$, and latitude of adaptation $(\mathrm{S}=$ southern and $\mathrm{N}=\mathrm{Northern})$.

by an electronic seed counter (Model 850-2; The Old Mill Company, Savage, MD).

\subsection{Seed Germination Testing}

Stratified seeds $\left(14 \mathrm{~d}\right.$ at $\left.5^{\circ} \mathrm{C}\right)$ were used for germination testing from March to May 2009 according to Association of Official Seed Analysts (ASOA) rules with no humidity control. Seeds were blotted and placed immediately to the testing temperature to minimize drying which induces secondary dormancy [34].

Preliminary studies at low temperature $\left(<20^{\circ} \mathrm{C}\right)$ indicated that fungal infection can affect germination, prompting the use of Captan \{cis-N-[(trichloromethyl)thio-4-cyclohexene-1,2- dicarboximide]\} at $0.55 \mathrm{~g} \cdot \mathrm{ai} \cdot \mathrm{kg}^{-1}$ seed as a drench prior to germination testing at all temperatures. Each genotype was replicated four times in a completely randomized design with 100 seed per replicate placed on a moistened single layer Whatman No. 1 filter paper (Whatman, Atlanta, GA) in a covered $90-\mathrm{cm}$ sterilized disposable plastic Petri dish to minimize moisture loss. Petri dishes were vertically stacked at constant set temperatures, 10 to $45^{\circ} \mathrm{C}$ at $5^{\circ} \mathrm{C}$ intervals. Constant light with a photon flux density of $35 \pm 2.6 \mu \mathrm{mol} \cdot \mathrm{m}^{2} \cdot \mathrm{s}^{-1}$ was provided by cool white fluorescent lamps during a 12-h light period, for all genotypes and temperatures in five germination chambers (Fisher Scientific, Suwanee, GA). Petri dishes were monitored daily to ensure that the filter paper remained moist and watered when necessary with distilled water.

Replicates for each genotype were completely randomized within the germination chamber for each temperature. To minimize the potential of small temperature changes within the chambers, the Petri dishes were rearranged every $6 \mathrm{~h}$. Germinated seeds were counted, recorded and discarded every $6 \mathrm{~h}$. Counts were discontinued if no seed germinated for five consecutive days. A seed was considered germinated when the coleoptile or coleorhizae was at least $2 \mathrm{~mm}$ long. 


\subsection{Curve Fitting Procedure and Data Analysis}

Temperature and germination time-course data were fitted with a 3-parameter Sigmoidal function (Equation (1)) using SigmaPlot 11 [35]. This function estimated the maximum cumulative seed germination percentage (germination capacity); the shape and steepness of the curve; and time to reach $50 \%$ of maximum germination. The rate of development was derived by the reciprocal of time to $50 \%$ of maximum seed germination.

$$
G=G_{\max } /\left\{1+\exp \left[-\left(x-x_{50}\right) / G_{\text {rate }}\right]\right\}
$$

where $G$ is the total seed germination percentage, $G_{\max }$ is the maximum cumulative seed germination percentage, $x_{50}$ is the time to $50 \%$ maximum seed germination, and $G_{\text {rate }}$ is the slope of the curve.

Maximum seed germination and germination rate responses to temperature were analyzed using linear and nonlinear regression techniques for all genotypes [31]. Based on the highest coefficient of determination $\left(r^{2}\right)$ value and the root mean square error (RMSE), the best curve fitting model was obtained. Accordingly, maximum seed germination was modeled using a quadratic function $\left(r^{2}=0.88\right.$, RMSE $\left.=5.2\right)$ while germination rate was modeled by a modified bilinear function $\left(r^{2}=0.95\right.$, RMSE $=1.00$ ). Quadratic and modified bilinear equations estimates for each replicate within each genotype were estimated using PROC NLIN of SAS [36] with a modified Newton Gauss iterative method. For the quadratic model (Equation (2)), the three cardinal temperatures $\left(\mathrm{T}_{\min }, \mathrm{T}_{\mathrm{opt}}\right.$ and $\left.\mathrm{T}_{\max }\right)$, were estimated using Equation (3) to (5).

$$
\begin{gathered}
\mathrm{MSG}=a+b \mathrm{~T}+c \mathrm{~T}^{2} \\
\mathrm{~T}_{\mathrm{opt}}=-b /(2 c) \\
\mathrm{T}_{\text {min }}=-b+\left(\sqrt{b^{2}}-4 a c\right) / 2 c \\
\mathrm{~T}_{\text {max }}=-b+\left(\sqrt{b^{2}}-4 a c\right) / 2 c
\end{gathered}
$$

where MSG is the maximum seed germination, $T_{\mathrm{opt}}, \mathrm{T}_{\min }$ and $\mathrm{T}_{\max }$ are the optimum, minimum, and maximum cardinal temperatures for seed germination, respectively, $\mathrm{T}$ is treatment temperature at which MSG was determined, and $\mathrm{a}, \mathrm{b}$, and $\mathrm{c}$ are genotype-specific constants generated using PROC GLM in SAS [36]. For the modified bilinear model using Equation (6), $\mathrm{T}_{\mathrm{opt}}$ was generated using SAS [36] while $T_{\min }$ and $T_{\max }$ were estimated using Equation (7) and (8).

$$
\mathrm{GR}=a+b_{1}\left(\mathrm{~T}-\mathrm{T}_{\mathrm{opt}}\right)+b_{2} \times \mathrm{ABS}\left(\mathrm{T}_{\mathrm{opt}}-\mathrm{T}\right)
$$

$$
\begin{aligned}
& \mathrm{T}_{\text {min }}=\left[a+\left(b_{2}-b_{1}\right) \times \mathrm{T}_{\text {opt }}\right] / b_{1}-b_{2} \\
& \mathrm{~T}_{\text {max }}=\left[a-\left(b_{2}+b_{1}\right) \times \mathrm{T}_{\mathrm{opt}}\right] / b_{1}+b_{2}
\end{aligned}
$$

where GR is germination rate, $T_{\text {opt }}, T_{\min }$, and $T_{\max }$ is the optimum, minimum, and maximum cardinal temperatures for seed germination, respectively, $\mathrm{T}$ is the treatment temperature, and $a, b_{1}$ and $b_{2}$ are genotype-specific constants generated using PROC NLIN in SAS [36].

\subsection{Cumulative Temperature Response Index (CTRI)}

Switchgrass genotypes were classified into cold or heat tolerant groups based on the summation of individual temperature response index values following the protocol used by Salem et al. [30] for pollen germination response to temperature. Accordingly, heat CTRI (H-CTRI) was calculated as the MSG and GR values for each of the cardinal temperatures $\left(T_{\min }, T_{\text {opt }}\right.$ and $\left.T_{\max }\right)$ of a specific genotype, divided by the maximum value observed among all genotypes (Equation [9]) while cold CTRI (C-CTRI) was determined by dividing the minimum value among all genotypes by the value of a specific genotype (Equation [10]), where $\mathrm{h}$ and t refers to maximum and genotype-specific parameter values. Genotypes were classified based on CTRI of all parameters as coldtolerant (>minimum CTRI + 4 standard deviations [SD]), moderately cold-tolerant ( $>$ minimum CTRI +3 SD), moderately cold-sensitive ( $>$ minimum CTRI $+2 \mathrm{SD}$ ), and cold-sensitive ( $>$ minimum CTRI $+1 \mathrm{SD})$. Similarly, genotypes were classified as heat-sensitive ( $>$ minimum $\mathrm{CTRI}+1 \mathrm{SD})$, intermediate $(>$ minimum CTRI $+2 \mathrm{SD})$, and heat tolerant $(>$ minimum CTRI $+3 \mathrm{SD})$.

All cumulative germination data were arcsine transformed prior to analysis and back transformed for reporting. Replicated values of cardinal temperatures $\left(\mathrm{T}_{\min }\right.$, $\mathrm{T}_{\mathrm{opt}}$, and $\left.\mathrm{T}_{\max }\right)$, temperature adaptability range $(\mathrm{TAR}=$ $\left.\mathrm{T}_{\max }-\mathrm{T}_{\min }\right)$, and MSG were analyzed using the ANOVA procedure (PROC GLM) in SAS [36] to determine the

$$
\begin{aligned}
& \text { H-CTRI }=\left(\frac{\text { MSG T }_{\text {min }_{t}}}{\text { MSG T }_{\text {min }_{h}}}+\frac{\text { MSG T }_{\text {opt }_{t}}}{\text { MSG T }_{\text {opt }_{h}}}+\frac{\text { MSG T }_{\text {max }_{t}}}{\text { MSG T }_{\text {max }_{h}}}\right.
\end{aligned}
$$

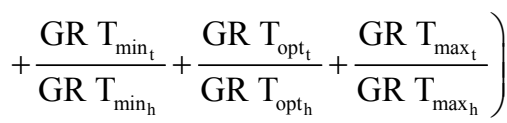

$$
\begin{aligned}
& \text { C-CTRI }=\left(\frac{\text { MSG T }_{\text {min }_{\mathrm{h}}}}{\text { MSG T }_{\text {min }_{\mathrm{t}}}}+\frac{\text { MSG T }_{\text {opt }_{\mathrm{h}}}}{\mathrm{MSG} \mathrm{T}_{\text {opt }_{\mathrm{t}}}}+\frac{\text { MSG T }_{\text {max }_{\mathrm{h}}}}{\mathrm{MSG} \mathrm{T}_{\text {max }_{\mathrm{t}}}}\right.
\end{aligned}
$$

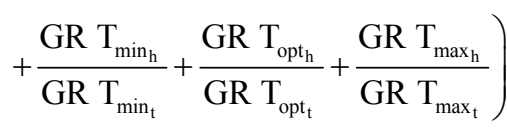


effect of temperature treatment on MSG and GR and their respective cardinal temperatures $\left(T_{\min }, T_{\text {opt }}\right.$, and $\left.\mathrm{T}_{\max }\right)$. Cardinal temperatures for MSG and GR parameter means were separated using Fishers protected least significant differences (LSD) at $P=0.05$. Germination parameters (MSG and GR) were treated as dependent variables while temperature and time to germination as independent variables. Regression analysis was carried out using SigmaPlot 11.0. Also, the mean seed germination parameters response to temperature was tested based on lowland (Alamo, Expresso, Kanlow and Tusca) or upland (Blackwell, Carthage, Cave-in-Rock, Dacotah, Forestburg, Shawnee, Shelter, Summer, Sunburst and Trailblazer) ecotypes using Fishers protected least significant differences (LSD) at $P=0.05$.

\section{Results}

\subsection{Germination Time Courses}

The 3-parameter Sigmoidal function fitted the cumulative germination time course (mean $r^{2}=0.98$ ) of genotypes response to temperature efficiently, illustrating the variability of genotypes in their germination characteristics (Figure 1). For clarity, only data and fitted lines for four genotypes, each representative of northern and southern upland (Cave-in-Rock and Shelter) and lowland (Alamo and Kanlow) ecotypes are presented. There was no germination at 10 or at $45^{\circ} \mathrm{C}$ in any of the genotypes tested.

\subsection{Maximum Seed Germination Response to Temperature}

Among the linear and nonlinear regression models tested, the quadratic function best described the response of MSG to temperature (mean $r^{2}=0.93$, RMSE $=5.2$ ). For clarity, only data and fitted lines for four genotypes, each representative of Northern and southern upland (Cavein-Rock and Shelter) and lowland (Alamo and Kanlow) genotypes are presented (Figure 2). Maximum seed germination varied $(P<0.001)$ among genotypes with a mean of $73 \%$ and ranged from 41 (Alamo) to $93 \%$ (Expresso) (Table 2). Cardinal temperatures $\left(\mathrm{T}_{\min }, \mathrm{T}_{\mathrm{opt}}\right.$, and $\left.\mathrm{T}_{\max }\right)$ for MSG also differed among the genotypes $(P$

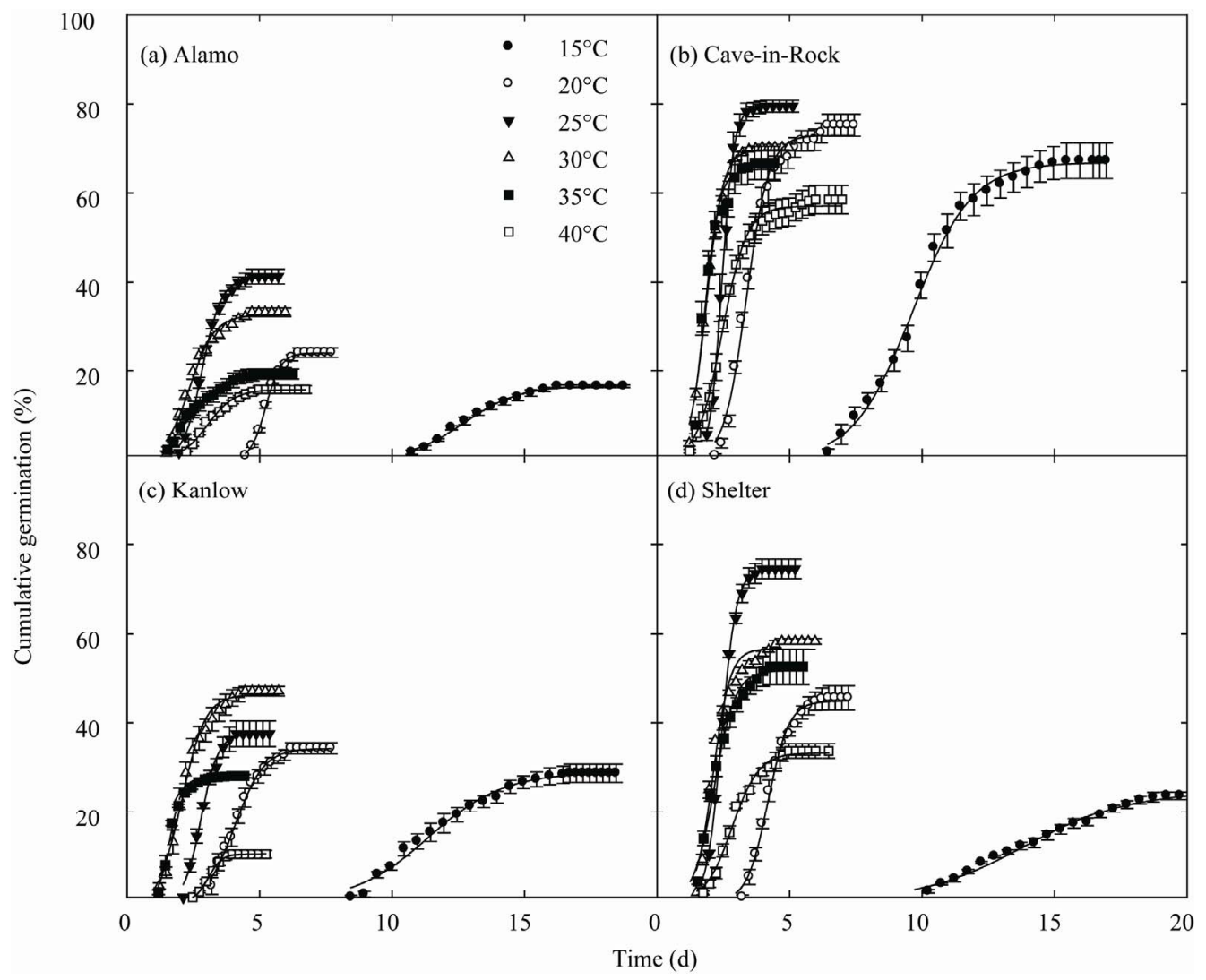

Figure 1. Germination time courses for seeds of (a) Alamo, (b) Cave-in-Rock, (c) Kanlow and (d) Shelter switchgrass germinated at a range of temperature $\left(15^{\circ} \mathrm{C}-40^{\circ} \mathrm{C}\right)$. The symbols indicate the observed cumulative germination data and the lines indicate the germination time courses fitted using a three-parameter sigmoidal function. Data are means and \pm SE of four replications. 


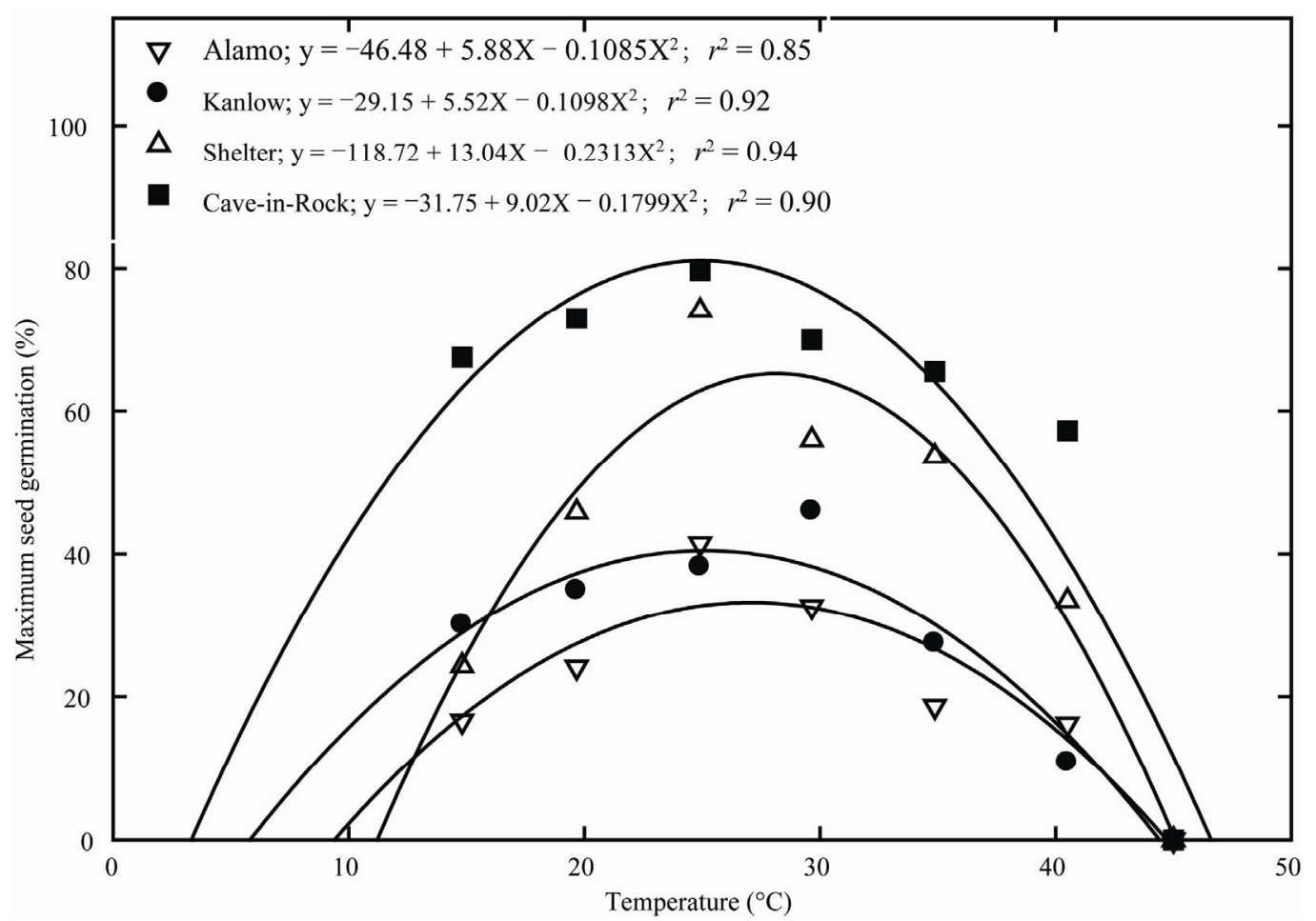

Figure 2. Influence of temperature on maximum seed germination and along with the fitted quadratic equations of four switchgrass genotypes (Alamo, Kanlow, Shelter, and Cave-in-Rock). The symbols are recorded maximum germination percentages and the curves are fitted lines using quadratic functions.

Table 2. Maximum seed germination percentage (MSG), temperature adaptability range (TAR), quadratic equation constants $(a, b$, and $c)$, regression coefficients $\left(r^{2}\right)$, and cardinal temperatures $\left(T_{\min }, T_{\text {opt }}\right.$, and $\left.T_{\max }\right)$ for maximum seed germination (MSG) of 14 switchgrass genotypes in response to temperature.

\begin{tabular}{|c|c|c|c|c|c|c|c|c|c|}
\hline \multirow{2}{*}{ Genotype } & \multirow{2}{*}{ MSG (\%) } & \multirow{2}{*}{$\operatorname{TAR}\left({ }^{\circ} \mathrm{C}\right)$} & \multicolumn{3}{|c|}{ Equation constants } & \multirow[t]{2}{*}{$\mathrm{r}^{2}$} & \multicolumn{3}{|c|}{ Cardinal temperatures $\left({ }^{\circ} \mathrm{C}\right)$} \\
\hline & & & $a$ & $b$ & c & & $\mathrm{T}_{\min }$ & $\mathrm{T}_{\mathrm{opt}}$ & $\mathrm{T}_{\max }$ \\
\hline Alamo & $40.97 \pm 1.56$ & $34.94 \pm 0.14$ & -46.48 & 5.88 & -0.1085 & 0.85 & $9.61 \pm 0.19$ & $27.08 \pm 0.12$ & $44.55 \pm 0.05$ \\
\hline Blackwell & $83.23 \pm 2.16$ & $36.01 \pm 0.25$ & -119.03 & 15.28 & -0.2798 & 0.98 & $9.33 \pm 0.32$ & $27.34 \pm 0.20$ & $45.34 \pm 0.10$ \\
\hline Carthage & $55.09 \pm 1.39$ & $35.51 \pm 0.44$ & -80.43 & 9.68 & -0.1733 & 0.93 & $10.2 \pm 0.35$ & $27.95 \pm 0.13$ & $45.71 \pm 0.11$ \\
\hline Cave-in-Rock & $79.48 \pm 1.38$ & $40.53 \pm 1.03$ & -31.75 & 9.02 & -0.1799 & 0.90 & $5.62 \pm 0.96$ & $25.88 \pm 0.45$ & $46.14 \pm 0.10$ \\
\hline Dacotah & $85.68 \pm 3.36$ & $34.25 \pm 0.39$ & -124.87 & 15.25 & -0.2786 & 0.97 & $10.4 \pm 0.41$ & $27.52 \pm 0.22$ & $44.64 \pm 0.09$ \\
\hline Expresso & $93.07 \pm 0.55$ & $43.38 \pm 0.62$ & -41.99 & 11.12 & -0.2176 & 0.79 & $3.69 \pm 0.48$ & $25.38 \pm 0.18$ & $47.07 \pm 0.16$ \\
\hline Forestburg & $80.76 \pm 2.72$ & $37.26 \pm 0.23$ & -72.49 & 11.38 & -0.2172 & 0.95 & $7.68 \pm 0.13$ & $26.31 \pm 0.10$ & $44.95 \pm 0.17$ \\
\hline Kanlow & $53.05 \pm 6.74$ & $37.95 \pm 1.09$ & -29.15 & 5.52 & -0.1098 & 0.92 & $6.40 \pm 0.97$ & $25.37 \pm 0.43$ & $44.34 \pm 0.15$ \\
\hline Shawnee & $50.31 \pm 1.85$ & $35.41 \pm 0.26$ & -74.79 & 9.25 & -0.1675 & 0.98 & $9.90 \pm 0.26$ & $27.60 \pm 0.14$ & $45.31 \pm 0.05$ \\
\hline Shelter & $74.27 \pm 2.39$ & $33.47 \pm 0.20$ & -118.72 & 13.04 & -0.2313 & 0.94 & $11.46 \pm 0.21$ & $28.19 \pm 0.12$ & $44.92 \pm 0.08$ \\
\hline Summer & $67.52 \pm 1.32$ & $31.47 \pm 0.27$ & -151.20 & 14.61 & -0.2525 & 0.95 & $12.83 \pm 0.11$ & $28.56 \pm 0.09$ & $44.30 \pm 0.21$ \\
\hline Sunburst & $86.95 \pm 0.21$ & $40.65 \pm 1.75$ & -60.75 & 11.39 & -0.2213 & 0.98 & $5.49 \pm 1.07$ & $25.81 \pm 0.38$ & $46.14 \pm 0.82$ \\
\hline Trailblazer & $87.46 \pm 1.98$ & $41.78 \pm 0.94$ & -42.23 & 10.63 & -0.2114 & 0.94 & $4.19 \pm 0.84$ & $25.08 \pm 0.37$ & $45.97 \pm 0.14$ \\
\hline Tusca & $89.56 \pm 0.78$ & $35.54 \pm 1.33$ & -76.87 & 12.88 & -0.2430 & 0.90 & $6.27 \pm 0.82$ & $24.04 \pm 0.48$ & $41.81 \pm 0.82$ \\
\hline Mean & 73.39 & 37.01 & - & - & - & 0.93 & 8.08 & 26.58 & 45.09 \\
\hline LSD & $12.66^{*}$ & $4.09^{*}$ & - & - & - & & $3.09^{*}$ & $1.43^{*}$ & $1.70^{*}$ \\
\hline
\end{tabular}

"Significant at $P=0.05$ probability level. 
$<0.001$ ). The $\mathrm{T}_{\min }$ values ranged from 3.69 (Expresso) to $12.83^{\circ} \mathrm{C}$ (Summer) with a mean of $8.08^{\circ} \mathrm{C}$. The $\mathrm{T}_{\text {opt }}$ was $26.58^{\circ} \mathrm{C}$ (Table 2); however, there was variation among the genotypes $(P<0.001)$. Summer recorded the highest $\mathrm{T}_{\text {opt }}\left(28.56^{\circ} \mathrm{C}\right)$ while Tusca showed the lowest $\left(24.04^{\circ} \mathrm{C}\right)$. The $\mathrm{T}_{\max }$ ranged from 41.81 (Tusca) to $47.07^{\circ} \mathrm{C}$ (Expresso) with a mean of $45.07^{\circ} \mathrm{C}$ (Table 2). The TAR for MSG ranged from 43.38 (Expresso) to $31.37^{\circ} \mathrm{C}$ (Summer) with a mean of $37^{\circ} \mathrm{C}$ for all genotypes.

Grouping genotypes based on upland and lowland ecotype revealed no differences $(P>0.05)$ for $\mathrm{MSG}$, TAR, $\mathrm{T}_{\min }$ and $\mathrm{T}_{\max }$; however, $\mathrm{T}_{\mathrm{opt}}$ for MSG was different $(P=0.0471$, LSD $=1.53)$ with mean of 27.02 and $25.47^{\circ} \mathrm{C}$ for upland and lowland ecotypes, respectively. Maximum seed germination for both upland and lowland ecotypes also varied ( $10 \%$ ) (data not shown). Cardinal temperature $\left(\mathrm{T}_{\min }, \mathrm{T}_{\mathrm{opt}}\right.$ and $\left.\mathrm{T}_{\max }\right)$ variation was small between ecotypes $(<4 \%)$. Maximum seed germination $\mathrm{T}_{\min }$ was more variable than $\mathrm{T}_{\mathrm{opt}}$ and $\mathrm{T}_{\max }$ for both upland and lowland ecotypes. On average, MSG cardinal temperatures were 10 and $6 \%$ more variable than germination rate cardinal temperatures for upland and lowland ecotypes, respectively.

\subsection{Germination Rate Response to Temperature}

The modified bilinear equation best described the relationship between GR and temperature (mean $r^{2}=0.95$, RMSE $=1.0$ ) among the linear and non-linear models tested. Cardinal temperatures for GR differed among genotypes $(P<0.05)$ (Table 3$)$. For clarity, only data and predictor lines of four genotypes are presented in Figure 3. The $\mathrm{T}_{\min }$ ranged from 9.09 (Dacotah) to $12.92^{\circ} \mathrm{C}$ (Shelter) with a mean of $11.13^{\circ} \mathrm{C}$. A mean of $33.12^{\circ} \mathrm{C}$ was estimated for $\mathrm{T}_{\text {opt }}$ which ranged from 29.55 (Shelter) to $35.73^{\circ} \mathrm{C}$ (Tusca). Highest $\mathrm{T}_{\max }$ was recorded in Shelter $\left(48.15^{\circ} \mathrm{C}\right)$, while the lowest $\mathrm{T}_{\max }\left(45.0^{\circ} \mathrm{C}\right)$ was observed in Kanlow. The TAR ranged from 32.92 (Blackwell) to $36.18^{\circ} \mathrm{C}$ (Dacotah) with a mean of $34.88^{\circ} \mathrm{C}$ (Table 3). Ecotypic classification of genotypes indicate that TAR, $\mathrm{T}_{\min }$ and $\mathrm{T}_{\max }$ did not differ, but $\mathrm{T}_{\mathrm{opt}}$ was different $(P<0.05)$ with a mean of 32.37 and $34.98^{\circ} \mathrm{C}$ for upland and lowland ecotypes, respectively $(P=0.0477$; LSD $=2.57)$. Cardinal temperatures variation was small between ecotypes $(<4 \%)$ with germination rate $\mathrm{T}_{\min }$ being more variable than $\mathrm{T}_{\mathrm{opt}}$ and $\mathrm{T}_{\max }$ for both upland and lowland ecotypes (Table 3).

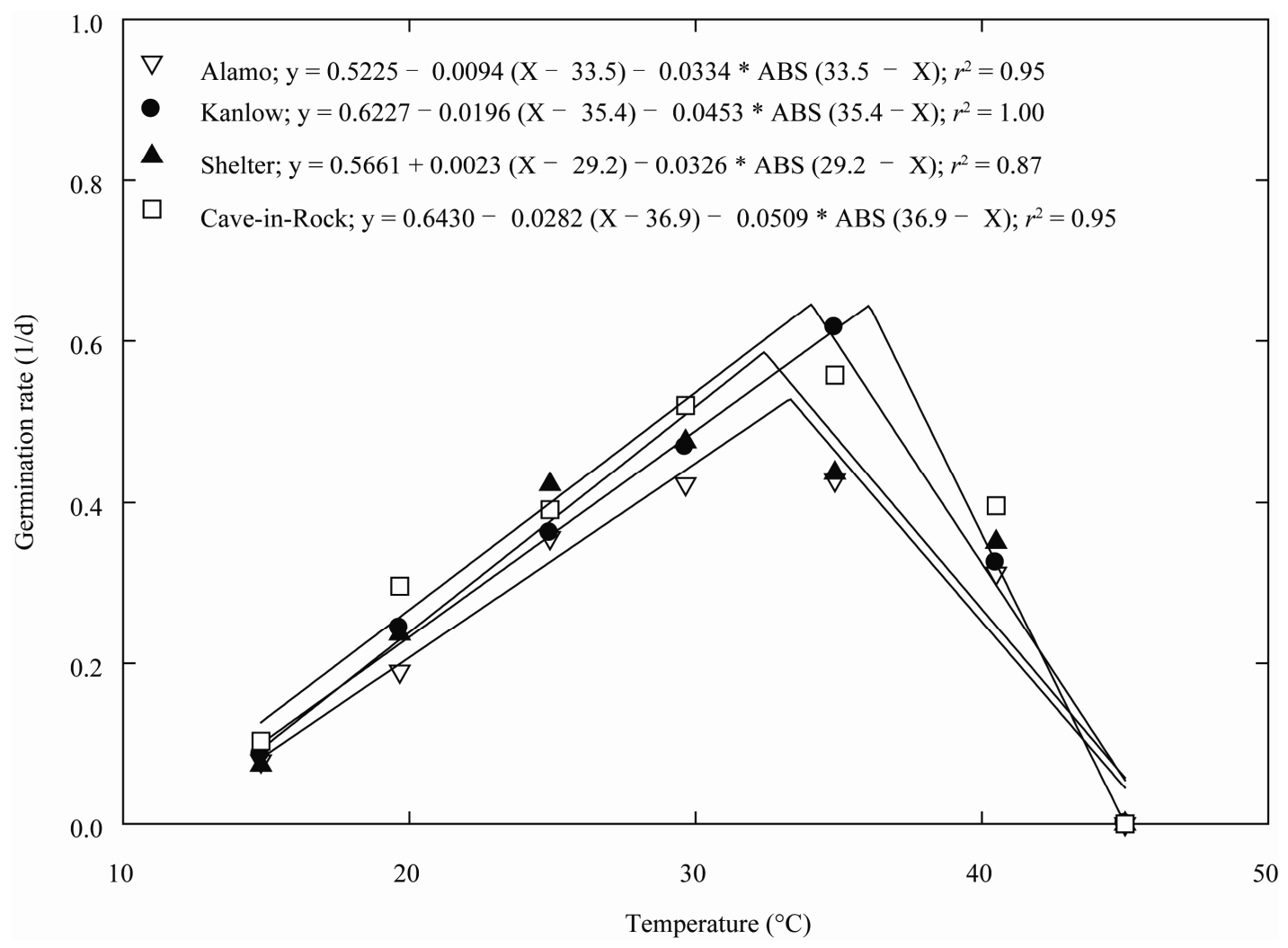

Figure 3. Effect of temperature on germination rate along with the fitted modified bilinear fitted lines and equations of four switchgrass genotypes (Alamo, Kanlow, Shelter, and Cave-in-Rock). The symbols are the derived germination rate and the lines are predicted values by the fitted modified bilinear equations. 
Table 3. Temperature adaptability range (TAR), modified bilinear equation constants $(a, b$, and $c)$, regression coefficients $\left(r^{2}\right)$, and cardinal temperatures $\left(T_{\min }, T_{\text {opv }}\right.$ and $\left.T_{\max }\right)$ for germination rate of 14 switchgrass genotypes in response to temperature.

\begin{tabular}{|c|c|c|c|c|c|c|c|c|}
\hline \multirow{2}{*}{ GeNotype } & \multirow{2}{*}{$\operatorname{TAR}\left({ }^{\circ} \mathrm{C}\right)$} & \multicolumn{3}{|c|}{ Equation Constants } & \multirow{2}{*}{$r^{2}$} & \multicolumn{3}{|c|}{ Cardinal temperatures $\left({ }^{\circ} \mathrm{C}\right)$} \\
\hline & & $a$ & $b$ & c & & $\mathrm{T}_{\min }$ & $\mathrm{T}_{\mathrm{opt}}$ & $\mathrm{T}_{\max }$ \\
\hline Alamo & $34.29 \pm 0.86$ & 0.5255 & -0.0094 & -0.0334 & 0.95 & $11.96 \pm 0.60$ & $33.02 \pm 1.40$ & $46.25 \pm 0.78$ \\
\hline Blackwell & $32.92 \pm 0.26$ & 0.6791 & -0.0142 & -0.0459 & 1.00 & $12.14 \pm 0.21$ & $33.91 \pm 0.08$ & $45.06 \pm 0.07$ \\
\hline Carthage & $34.06 \pm 0.47$ & 0.5945 & 0.0010 & -0.0349 & 0.87 & $12.83 \pm 0.22$ & $30.45 \pm 1.00$ & $46.89 \pm 0.64$ \\
\hline Cave-in-Rock & $35.11 \pm 0.57$ & 0.6430 & -0.0282 & -0.0509 & 0.98 & $10.16 \pm 0.60$ & $34.43 \pm 0.88$ & $45.27 \pm 0.37$ \\
\hline Dacotah & $36.18 \pm 0.30$ & 0.6469 & -0.0266 & -0.0496 & 0.97 & $9.09 \pm 0.49$ & $35.34 \pm 0.88$ & $45.27 \pm 0.26$ \\
\hline Expresso & $35.77 \pm 0.53$ & 0.7545 & -0.0290 & -0.0566 & 0.98 & $9.33 \pm 0.63$ & $35.50 \pm 0.83$ & $45.09 \pm 0.10$ \\
\hline Forestburg & $35.17 \pm 0.44$ & 0.5884 & -0.0121 & -0.0374 & 0.98 & $10.18 \pm 0.52$ & $34.03 \pm 0.78$ & $45.35 \pm 0.12$ \\
\hline Kanlow & $35.06 \pm 0.84$ & 0.6227 & -0.0196 & -0.0453 & 1.00 & $9.94 \pm 0.84$ & $35.65 \pm 0.26$ & $45.00 \pm 0.00$ \\
\hline Shawnee & $35.01 \pm 0.45$ & 0.5940 & 0.0024 & -0.0338 & 0.82 & $12.54 \pm 0.26$ & $30.56 \pm 1.05$ & $47.55 \pm 0.71$ \\
\hline Shelter & $35.23 \pm 0.15$ & 0.5661 & 0.0023 & -0.0326 & 0.87 & $12.92 \pm 0.08$ & $29.55 \pm 0.07$ & $48.15 \pm 0.10$ \\
\hline Summer & $35.02 \pm 0.36$ & 0.4765 & 0.0009 & -0.0270 & 0.86 & $12.06 \pm 0.49$ & $30.77 \pm 1.36$ & $47.08 \pm 0.68$ \\
\hline Sunburst & $35.35 \pm 0.34$ & 0.6072 & -0.0008 & -0.0343 & 0.89 & $11.21 \pm 0.23$ & $30.48 \pm 1.04$ & $46.55 \pm 0.50$ \\
\hline Trailblazer & $35.59 \pm 0.18$ & 0.7006 & -0.0273 & -0.0524 & 0.97 & $9.86 \pm 0.27$ & $34.21 \pm 0.39$ & $45.44 \pm 0.15$ \\
\hline Tusca & $33.52 \pm 0.39$ & 0.6361 & -0.0089 & -0.0384 & 0.90 & $11.65 \pm 0.34$ & $35.73 \pm 1.02$ & $45.16 \pm 0.22$ \\
\hline Mean & 34.88 & - & - & - & 0.93 & 11.13 & 33.12 & 46.01 \\
\hline LSD & $2.47^{*}$ & - & - & - & - & $2.32^{*}$ & $4.49^{*}$ & $2.17^{*}$ \\
\hline
\end{tabular}

*Significant at $P=0.05$ probability level.

\subsection{Genotype Classification Using Cumulative Temperature Response Index (CTRI)}

Six parameters $\left(T_{\min }, T_{\text {opt }}\right.$, and $T_{\max }$ for both MSG and GR) were used for both heat- and cold-tolerance classification of genotypes based on CTRI. Each parameter contributed differently based on its relation to the minimum or maximum value for that parameter across the genotypes. Using one standard deviation permitted the classification of heat-CTRI values (which ranged from 4.83 to 6.05 ) into three groups (heat-sensitive [4.83 5.43 ]; intermediate [5.44 - 5.74], and heat-tolerant [5.73 6.05]). Summer was identified as the most heat-tolerant genotype while Cave-in-Rock, Dacotah, Expresso, Forestburg, Kanlow, Sunburst, Trailblazer and Tusca as heat-sensitive genotypes (Table 4).

Using the same parameters used for heat tolerance, the genotypes were similarly classified for cold-tolerance

(Table 4). Cold-CTRI values, which ranged from 4.74 to 6.21 , allowed grouping of genotypes into four tolerance categories (cold sensitive [4.74 - 5.03]; moderately cold sensitive [5.04 - 5.32], moderately cold tolerant [5.33 - 5.62], and cold tolerant [5.63 - 6.21]). Expresso had the highest cold-CTRI (5.64), and therefore considered as most cold-tolerant genotype, while Summer had the lowest cold-CTRI (4.74) and was classified as cold-sensitive genotype (Table 4).

\subsection{Parameter Relationships}

No correlation was found between MSG $T_{\min }$ and $T_{\max }$ and $\mathrm{T}_{\text {opt }}$ and $\mathrm{T}_{\max }(P>0.05)$, however, a positive linear correlation existed between $\mathrm{T}_{\min }$ and $\mathrm{T}_{\text {opt }}\left(r^{2}=0.81, P<\right.$ 0.0001). As GR $\mathrm{T}_{\text {min }}$ increased among the genotypes, $\mathrm{T}_{\max }$ generally increased $\left(r^{2}=0.56, P<0.0021\right)$. An inverse relationship was found between GR $\mathrm{T}_{\min }$ and $\mathrm{T}_{\mathrm{opt}}$ $\left(r^{2}=0.58, P<0.0014\right)$ as well as $\mathrm{T}_{\text {opt }}$ and $\mathrm{T}_{\max }\left(r^{2}=0.88\right.$, $P<0.0001)$. The correlation between MSG and GR cardinal temperatures varied, but a weak positive correlation was found between MSG and GR $\mathrm{T}_{\min }\left(r^{2}=0.39, P=\right.$ $0.0163)$, while a weak negative correlation was found between MSG and GR $\mathrm{T}_{\text {opt }}\left(r^{2}=0.46, P=0.0071\right)$. 
Table 4. Classification of switchgrass genotypes into (a) heat-tolerance and (b) cold-tolerance groups based on cumulative temperature response index (CTRI; unitless) along with individual scores in parenthesis.

(a) Heat-tolerance classification based on CTRI

\begin{tabular}{|c|c|c|c|}
\hline $\begin{array}{c}\text { Heat-sensitive } \\
(\mathrm{CTRI}=4.83-5.43)\end{array}$ & $\begin{array}{c}\text { Intermediate } \\
(\mathrm{CTRI}=5.44-5.74)\end{array}$ & $\begin{array}{c}\text { Heat-tolerant } \\
(\mathrm{CTRI}=5.75-6.05)\end{array}$ & \\
\hline Expresso (4.83) & Alamo (5.45) & Summer (5.78) & \\
\hline Trailblazer (4.85) & Blackwell (5.47) & & \\
\hline Sunburst (5.0) & Shawnee (5.51) & & \\
\hline Cave-in-Rock (5.01) & Carthage (5.56) & & \\
\hline Kanlow (5.03) & Shelter (5.59) & & \\
\hline \multicolumn{4}{|l|}{ Tusca (5.06) } \\
\hline \multicolumn{4}{|l|}{ Forestburg (5.16) } \\
\hline \multicolumn{4}{|l|}{ Dacotah (5.36) } \\
\hline \multicolumn{4}{|c|}{ (b) Cold-tolerance classification based on CTRI } \\
\hline $\begin{array}{c}\text { Cold-sensitive } \\
(\mathrm{CTRI}=4.74-5.03)\end{array}$ & $\begin{array}{l}\text { Moderately cold-sensitive } \\
\quad(\mathrm{CTRI}=5.04-5.32)\end{array}$ & $\begin{array}{l}\text { Moderately cold-tolerant } \\
\quad(\text { CTRI }=5.33-5.62)\end{array}$ & $\begin{array}{c}\text { Cold-tolerant } \\
(\mathrm{CTRI}=5.63-6.21)\end{array}$ \\
\hline Shelter (4.74) & Forestburg, (5.08) & Trailblazer (5.52) & Expresso (5.64) \\
\hline Summer (4.74) & Tusca (5.19) & & \\
\hline Carthage (4.78) & Kanlow (5.21) & & \\
\hline Shawnee (4.8) & Cave-in-Rock (5.24) & & \\
\hline Blackwell (4.82) & Sunburst (5.26) & & \\
\hline \multicolumn{4}{|l|}{ Alamo (4.84) } \\
\hline Dacotah (5.0) & & & \\
\hline
\end{tabular}

\section{Discussion}

Seed germination is a complex physiological process modulated by internal and external factors and their interactions. Similar to other growth and developmental processes, temperature influences seed dormancy, germination capacity and rate, and seedling emergence. To our knowledge, this is the first study to evaluate the influence of temperature effects on seed germination characteristics of diverse switchgrass genotypes. The resulting data provided functional algorithms for modeling and segregating genotypes for cold- and heat-tolerance based on seed-based parameters.

Optimal temperatures for MSG and GR differed among the genotypes with MSG optimum occurring over a range and GR having a sharply defined optimum. Relative to MSG, GR had higher $T_{\min }, \mathrm{T}_{\text {opt }}$ and $\mathrm{T}_{\max }$ values consistent with previous reports that many species typically have higher optimum temperatures for GR than for MSG percentage [11]. Germination rate is more temperature sensitive than final germination percentage in Setaria lutescens and Amaranthus retroflexus [37] similar to our finding in switchgrass genotypes. Germination rate is affected by the depth of dormancy, imbibition rate and the rate of catabolic and anabolic pathways all of which are directly or indirectly temperature dependent while the maximum seed germination is more affected by the rate of rehydration rather than the speed of the physiological pathways affecting cell expansion.

\subsection{Maximum Seed Germination}

All switchgrass genotypes tested exhibited a quadratic response to temperature $\left(r^{2}=0.93\right)$, similar to indiangrass (Sorghastrum nutans (L.) Nash) tested under alternating temperature conditions [6], another native warm-season species. Mean MSG (73\%) in the current study is similar to the $77 \%$ to $78 \%$ reported for similar genotypes [1,2,5], although the temperature and lighting conditions across these experiments are divergent.

With the exception of Expresso, which has been selected for increased precocious germination (B. Baldwin, personal communication, 2009), MSG of the other two lowland genotypes (Alamo and Kanlow) were less than $55 \%$.

The optimum temperature for switchgrass MSG in the 
current study varied between $24.04^{\circ} \mathrm{C}$ and $28.56^{\circ} \mathrm{C}$ among the genotypes, which is within the range of values reported in other warm-season grasses; $20^{\circ} \mathrm{C}$ to $30^{\circ} \mathrm{C}$ for Cane beardgrass [Bothriochloa barbinodis (Lag.) Herter], sideoats grama [Bouteloua curtipendula (Michx.) Torr.], and tanglehead [Heteropogon contortus (L.) P. Beauv. ex Roem. \& Schult.] [38] and $16.5^{\circ} \mathrm{C}$ to $27^{\circ} \mathrm{C}$ for indiangrass [39]. Maximum seed germination minimum temperature averaged $8.08^{\circ} \mathrm{C}$ and ranged from 3.69 to $12.83^{\circ} \mathrm{C}$, which is similar to $\mathrm{T}_{\min }$ of other warm-season grasses [40]; $5.5^{\circ} \mathrm{C}$ to $10.9^{\circ} \mathrm{C}$ for switchgrass, $7.3^{\circ} \mathrm{C}$ to $8.7^{\circ} \mathrm{C}$ for big bluestem (Andropogon gerardii Vitman), $7.5^{\circ} \mathrm{C}$ to $9.6^{\circ} \mathrm{C}$ for indiangrass, and $4.5^{\circ} \mathrm{C}$ to $7.9^{\circ} \mathrm{C}$ for prairie sandreed (Calamovilfa longifolia (Hook.) Scribn.).

\subsection{Germination Rate}

Thermal response of switchgrass seed germination is consistent with thermal response patterns of a number of other physiological processes [41]. At suboptimal temperatures $\left(T_{\min }\right.$ to $T_{o p t}$ ), germination rate (reciprocal time to $50 \%$ germination) generally increases linearly with temperature, but decreases linearly with temperature at supra-optimal temperatures $\left(\mathrm{T}_{\text {opt }}\right.$ to $\left.\mathrm{T}_{\max }\right)$. This characteristic thermal response is similar to germination rate of chickpea (Cicer arietinum L.) [2,27], lentil (Lens culinaris Medic.) and soybean (Glycine max (L.) Merr.) [27], pearl millet (Pennisetum glaucum (L.) R. Br.) [42], sorghum [Sorghum bicolor (L.) Moench.] [43] and cool season weeds [44]. A decline in germination rate with decreasing temperature is partly associated with decline in the imbibition rate observed with a reduction in temperature [45]. Germination rate response to temperature was described previously by two linear equations; the first describing the positive linear relationship between the minimum and optimum temperatures and the second describing the negative linear relationship between optimum and maximum temperature $[2,27]$. In the current study, GR was modeled using a single modified bilinear equation, which was previously used by several studies $([30-33,46])$ to quantify pollen germination and pollen tube growth responses to temperature. Analogous to pollen, seeds are considered independent functional units that are responsive to temperature changes.

Even though MSG percentage is the most important parameter determining commercial value of seedlots, GR influences the uniformity and rapidity of emergence in nurseries [47]. Germination rates are most rapid at optimum temperature ranging from $29.5^{\circ} \mathrm{C}$ to $35.6^{\circ} \mathrm{C}$.

\subsection{Cardinal Temperatures}

Biological processes are typically characterized by cardinal temperatures describing the range of temperature over which a process can occur. The effect of temperature on seed germination can be expressed in terms of cardinal temperatures, that is, $T_{\min }, T_{\text {opt }}$, and $T_{\max }$ at which germination will occur [48]. Cardinal temperatures may be used to describe the range of adaptation of a species.

Though switchgrass is reported to be the most temperature specific of the warm-season grasses [15], there exists significant intra-specific differences in cardinal temperatures that may be related to the different areas of origin or adaptation [40,49]. The genotypes Cave-inRock, Dacotah, Forestburg, Shawnee, Shelter, Summer, Sunburst, and Trailblazer are from the cooler northern regions where average minimum temperatures range from $-23.3^{\circ} \mathrm{C}$ to $-17.8^{\circ} \mathrm{C}$, while Alamo, Blackwell, Expresso, Kanlow, and Tusca are from warmer growing regions with average minimum temperatures ranging from $-17.8^{\circ} \mathrm{C}$ to $4.4^{\circ} \mathrm{C}$. Cardinal temperature coefficients can be directly compared for screening germplasm [44]. The cardinal temperatures derived for both MSG and GR can be used in evaluation of potential regions for introduction of switchgrass and also aid in on-farm operational practices such as appropriate sowing dates when soil temperature would be conducive to optimum germination and emergence and ultimately optimum stand establishment and crop performance. Genotypes with lower $\mathrm{T}_{\min }$ values can be subjected to early-season sowing because of their inherent capacity to germinate in cooler temperatures. The variability of cardinal temperatures both for MSG and GR indicates broad latitudinal adaptation across the various plant hardiness zones of the USA [50].

The cardinal temperatures derived for GR may be comparable with subsequent developmental stages of switchgrass ontogeny (morphological development). Kiniry et al. [16] assumed a base temperature of $12^{\circ} \mathrm{C}$ for all growth stages of switchgrass in the ALMANAC model, however, the results in this study suggest that cardinal temperatures are genotype-specific and may be process-specific as well. Therefore, the derived cardinal temperatures in this study may be used to refine model algorithms for on-farm application and policy assessments.

\subsection{Temperature Tolerance Classification}

Temperature tolerance refers to the ability of an organism to cope with excessively high or low temperatures. Direct selection under field conditions is generally difficult because uncontrollable environmental factors affect the precision and repeatability of such trials. Stress tolerance is a developmentally regulated, stage-specific phenomenon; hence species may show different sensitivity to stress at different developmental stages. All stages through a plant's ontogeny are sensitive to temperature; 
therefore, screening for tolerance should be conducted at the most sensitive stage. Seed germination is temperature dependent and can be used to screen for temperature tolerance. In vitro assays are not subjected to uncontrollable biotic and abiotic stress factors marring true tolerance potential. In the field, genotypes with high minimum temperature would experience little germination in early spring when temperatures would frequently drop below the $\mathrm{T}_{\min }$ level.

In the current study, the successful use of CTRI, based on the summation of individual temperature response indices and then separated by standard deviation based on the number of classes of interest, confirms that seed-based parameters derived from in vitro seed germination assay can be used for genotype temperature tolerance classification. Genotype variability associated with temperature tolerance was demonstrated in this study. Alamo, Blackwell, Carthage, Dacotah, Shawnee, Shelter, and Summer were classified as cold-sensitive while Expresso was classified as cold-tolerant. Conversely, Cavein-Rock, Dacotah, Expresso, Forestburg, Kanlow, Sunburst, Trailblazer, and Tusca were determined to be heat-sensitive and Summer as heat-tolerant. Since basal temperature tolerance is a function of genetics and acquired temperature tolerance is latitude and temperature-induced, corroborating seed-based temperature tolerance with vegetative or other reproductive responses will validate the use of seed-based parameters as a screening tool. This information is lacking in the literature with respect to screening temperature tolerance of diverse switchgrass genotypes, even though several studies link intraspecific differences in germination to geographical and ecological areas of distribution or origin [51].

The classification method tested suggests that CTRI for heat- and cold-tolerance are inversely related $\left(r^{2}=\right.$ $0.64, P=0.0006$ ), suggesting that it may be difficult to identify a cultivar that possesses both heat- and coldtolerance characteristics (Figure 4). Variability among genotypes for heat- and cold-tolerance suggests that selection or breeding among genotypes is a viable objective. Switchgrass adaptation to a specific ecoclimatic and edaphic region is determined by the growth rate, photoperiodism, heat tolerance, and cold or freezing tolerance of a specific genotype [10].

Ecotype classification in this study did not necessarily confer the temperature tolerance characteristic of a specific ecotype. For example, Alamo, a lowland genotype, was classified as intermediately heat-tolerant while Summer, an upland genotype was classified as heattolerant using seed-based parameters. Genotype temperature tolerance is determined not only by ecotypic classification, but also latitude of origin, photoperiodism and

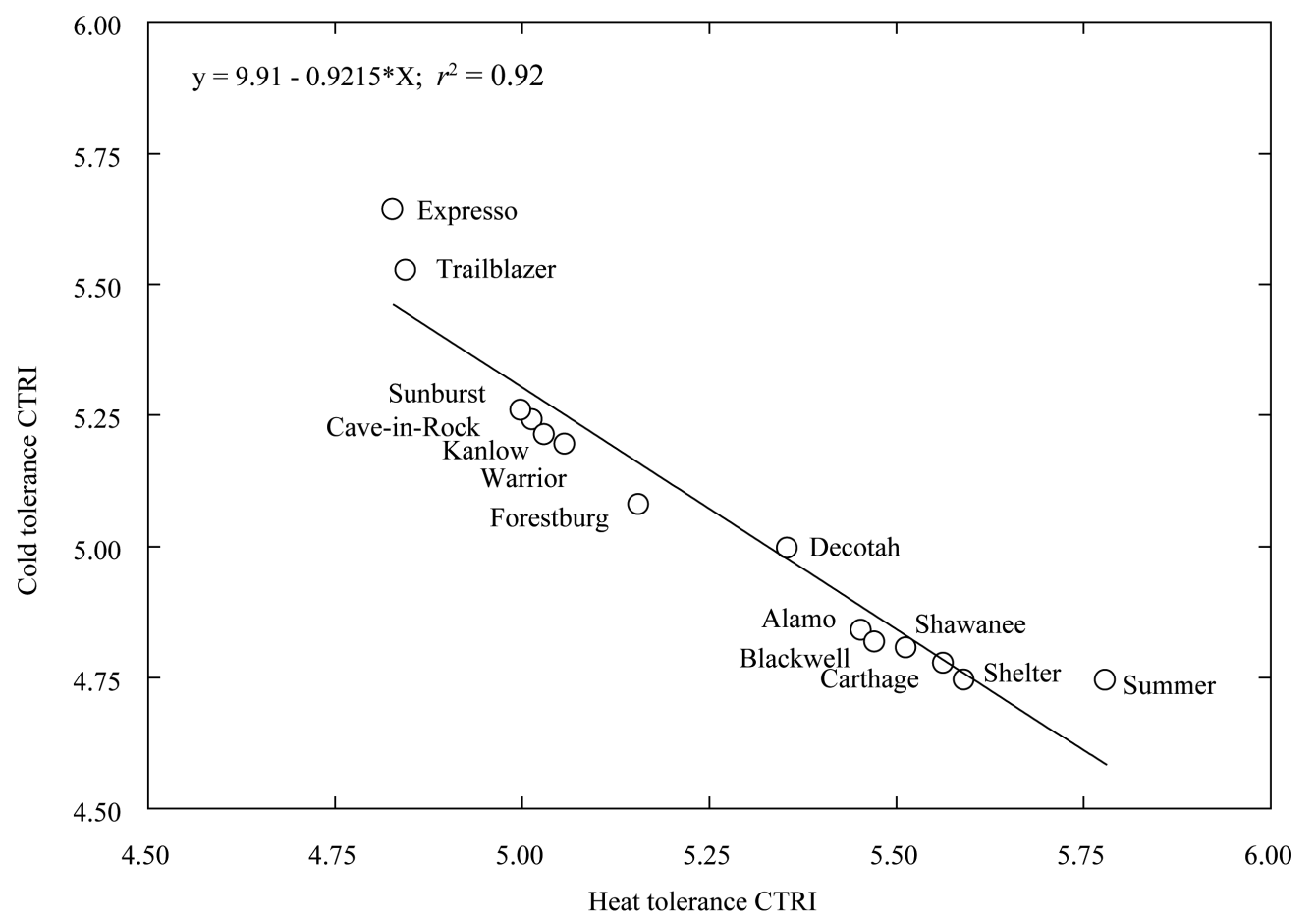

Figure 4. The relationship between heat- and cold-tolerance cumulative temperature response index (CTRI) for 14 switchgrass genotypes. 
genetics. Being photoperiod sensitive [52], switchgrass morphological development is determined primarily by its response to daylength [53]. Since ecotypic classification are more related to photoperiod responsiveness than temperature, the small or little variation observed between upland and lowland ecotypes for seed germination characteristics may be as result of ecotypic temperature insensitivity.

Since tolerance mechanisms are developmentally regulated, it is prudent to validate controlled in vitro seed germination assay with field performance tests. In the current study, GR and MSG were evaluated as estimators of temperature tolerance using 14 diverse genotypes. Using similar techniques, 12 genotypes of sorghum were screened for cold tolerance in controlled in vitro germination studies and GR was found to be strongly correlated with rate of emergence under field conditions, confirming that screening using parameters based on in vitro studies is a rapid and reliable method for handling large number of genotypes before evaluation in the field [26]. The current study quantified the relation between GR and temperature, highlighting genotypic differences. It is necessary in future work, therefore, to determine whether in vitro seed germination assay has potential in selection and screening procedures in breeding programs.

\section{Conclusions}

The current study quantified the effects of temperature on seed germination rate and capacity of 14 diverse switchgrass genotypes and determined the cardinal temperatures for MSG and GR. Genotypic variability for MSG, GR, their respective cardinal temperatures, and TAR were found to exist among the switchgrass genotypes tested. Mean minimum temperatures for MSG and GR were $8.08^{\circ} \mathrm{C}$ and $11.1^{\circ} \mathrm{C}$, respectively, while optimum temperatures were $26.6^{\circ} \mathrm{C}$ and $33.1^{\circ} \mathrm{C}$, respectively. The cumulative temperature response index method used in the current study identified both heat and cold tolerant genotypes and demonstrated that variability existed among genotypes and ecotypes. The cardinal temperature estimates would be useful to improve switchgrass models for field applications. Additionally, the identified coldand heat-tolerant genotypes can be selected for niche environments and in switchgrass breeding programs to develop new genotypes for cold and hot environments.

\section{Acknowledgements}

The authors are grateful to Ernst Seed Company for providing seeds of 5 switchgrass genotypes. This research was funded in part by the Department of Energy through Sustainable Energy Center, Mississippi State University, Mississippi State, MS, the USDA-UV-B Monitoring and
Research Program, and the USDA-ARS 58-6402-7-241. This article has been approved for publication as Journal Article No. J11898 of the Mississippi Agricultural and Forestry Experiment Station, Mississippi State University.

\section{REFERENCES}

[1] G. Hacisalihoglu, "Responses of Three Switchgrass (Panicum virgatum L.) Cultivars to Seed Priming and Differential Aging Conditions," Acta Agriculturae Scandinavica Section B-Soil and Plant Science, Vol. 58, No. 3, 2008, pp. 280-284.

[2] G. E. Aiken and T. L. Springer, "Seed Size Distribution, Germination, and Emergence of Six Switchgrass Cultivars," Journal of Range Management, Vol. 48, No. 5, 1995 , pp. 455-458. doi: $10.2307 / 4002252$

[3] F. H. Hsu, C. J. Nelson and W. S. Chow, "A Mathematical Model to Utilize the Logistic Function in Germination and Seedling Growth," Journal of Experimental Botany, Vol. 35, No. 11, 1984, pp. 1629-1640.

doi:10.1093/jxb/35.11.1629

[4] W. Robocker, J. Curtis and H. Ahlgren, "Some Factors Affecting Emergence and Establishment of Native Grass Seedlings in Wisconsin," Ecology, Vol. 34, No. 1, 1953, pp. 194-199. doi:10.2307/1930322

[5] J. D. Hanson and H. A. Johnson, "Germination of Switchgrass under Various Temperature and $\mathrm{pH}$ Regimes," Seed Technology, Vol. 27, No. 2, 2005, pp. 203-210.

[6] T. E. Fulbright, "Effects of Temperature, Water Potential and Sodium Chloride on Indiangrass Germination," Journal of Range Management, Vol. 41, No. 3, 1988, pp. 207 210. doi: $10.2307 / 3899168$

[7] S. B. McLaughlin and M. E. Walsh, "Evaluating Environmental Consequences of Producing Herbaceous Crops for Bioenergy," Biomass and Bioenergy, Vol. 14, No. 4, 1998, pp. 317-324. doi:10.1016/S0961-9534(97)10066-6

[8] M. K. Das, R. G. Fuentes and C. M. Taliaferro, "Genetic Variability and Trait Relationships in Switchgrass," Crop Science, Vol. 44, No. 2, 2004, pp. 443-448.

[9] S. A. Eberhart and L. C. Newell, "Variation in Domestic Collections of Switchgrass, Panicum virgatum L," Agronomy Journal, Vol. 51, No. 10, 1959, pp. 613-616. doi:10.2134/agronj1959.00021962005100100015x

[10] M. D. Casler, et al., "Latitudinal and Longitudinal Adaptation of Switchgrass Populations," Crop Science, Vol. 47, No. 6, 2007, pp. 2249-2260. doi:10.2135/cropsci2006.12.0780

[11] E. H. Roberts, "Temperature and Seed Germination," In: S. P. Long and F. I. Woodword, Eds., Plants and Temperature, Symposia of the Society for Experimental Biology, Cambridge, 1988, pp. 109-132.

[12] G. L. Jordan and M. R. Haferkamp, "Temperature Responses and Calculated Heat Units for Germination of Several Range Grasses and Shrubs," Journal of Range 
Management, Vol. 42, No. 1, 1989, pp. 41-45. doi: $10.2307 / 3899656$

[13] R. Ellis, E. Roberts and P. Hebblethwaite, "Towards a Rational Basis for Testing Seed Quality," In: P. Hebblethwaite, Ed., Seed Production, Butterworths, London, 1980, pp. 605-635.

[14] D. J. Parrish and J. H. Fike, "The Biology and Agronomy of Switchgrass for Biofuels," Critical Reviews in Plant Sciences, Vol. 24, No. 5-6, 2005, pp. 423-459. doi: $10.1080 / 07352680500316433$

[15] F. H. Hsu, C. J. Nelson and A. G. Matches, "Temperature Effects on Germination of Perennial Warm-Season Forage Grasses," Crop Science, Vol. 25, No. 2, 1985, pp. 215-215.

doi:10.2135/cropsci1985.0011183X002500020005x

[16] J. R. Kiniry, et al., "Switchgrass Simulation by the ALMANAC Model at Diverse Sites in the Southern US," Biomass and Bioenergy, Vol. 29, No. 6, 2005, pp. 419-425. doi:10.1016/j.biombioe.2005.06.003

[17] E. Heaton, T. Voigt and S. P. Long, "A Quantitative Review Comparing the Yields of Two Candidate C4 Perennial Biomass Crops in Relation to Nitrogen, Temperature and Water," Biomass and Bioenergy, Vol. 27, No. 1, 2004, pp. 21-30. doi:10.1016/j.biombioe.2003.10.005

[18] S. McLaughlin, et al., "Developing Switchgrass as a Bioenergy Crop," In: J. Janick, Ed., Perspectives on New Crops and New Uses, ASHS Press, Alexandria, 1999. pp. 282-289.

[19] P. S. Setimela, et al., "Screening Sorghum Seedlings for Heat Tolerance Using a Laboratory Method," European Journal of Agronomy, Vol. 23, No. 2, 2005, pp. 103-107. doi:10.1016/j.eja.2004.09.008

[20] M. Bouslama and W. T. Schapaugh Jr, "Stress Tolerance in Soybeans. I. Evaluation of Three Screening Techniques for Heat and Drought Tolerance," Crop Science, Vol. 24, No. 5,1984 , pp. 933-933. doi:10.2135/cropsci1984.0011183X002400050026x

[21] S. Sadasivam, et al., "Genetic Variation in Seed Germination, Root Traits and Drought Recovery in Rice," Indian Journal of Plant Physiology, Vol. 5, No. 1, 2000, pp. 73-78.

[22] M. R. Foolad and G. Y. Lin, "Genetic Potential for Salt Tolerance during Germination in Lycopersicon Species," HortScience, Vol. 32, 1997, pp. 296-300.

[23] N. Misra and U. N. Dwivedi, "Genotypic Difference in Salinity Tolerance of Green Gram Cultivars," Plant Science, Vol. 166, No. 5, 2004, pp. 1135-1142. doi:10.1016/j.plantsci.2003.11.028

[24] F. F. Hou and F. S. Thseng, "Studies on the Screening Technique for Pre-Germination Flooding Tolerance in Soybean," Japanese Journal of Crop Science, Vol. 61, No. 3, 1992, pp. 447-453. doi:10.1016/j.plantsci.2003.11.028

[25] S. N. Acharya, J. Dueck and R. K. Downey, "Selection and Heritability Studies on Canola/Rapeseed for Low Temperature Germination," Canadian Journal of Plant
Science, Vol. 63, No. 2, 1983, pp. 377-384.

doi:10.4141/cjps83-043

[26] I. Tiryaki and D. J. Andrews, "Germination and Seedling Cold Tolerance in Sorghum. I. Evaluation of Rapid Screening Methods," Agronomy Journal, Vol. 93, No. 6, 2001, pp. 1386-1391. doi:10.2134/agronj2001.1386

[27] S. Covell, et al., "The Influence of Temperature on Seed Germination Rate in Grain Legumes. I. A Comparison of Chickpea, Lentil, Soybean and Cowpea at Constant Temperatures," Journal of Experimental Botany, Vol. 37, No. 5, 1986, pp. 705-715. doi:10.1093/jxb/37.5.705

[28] B. N. Emerson and H. C. MiNor, "Response of Soybeans to High Temperature during Germination," Crop Science, Vol. 19, No. 4, 1979, pp. 553-553. doi:10.2135/cropsci1979.0011183X001900040029x

[29] S. Koti, et al., "Soybean (Glycine Max) Pollen Germination Characteristics, Flower and Pollen Morphology in Response to Enhanced Ultraviolet-B Radiation," Annals of Botany, Vol. 94, No. 6, 2004, pp. 855 doi:10.1093/aob/mch212

[30] M. A. Salem, et al., "Pollen-based Screening of Soybean Genotypes for High Temperatures," Crop Science, Vol. 47 , No. 1,2007 , pp. $219-231$ doi:10.2135/cropsci2006.07.0443

[31] V. G. Kakani, et al., "Response of in Vitro Pollen Germination and Pollen Tube Growth of Groundnut (Arachis hypogaea L.) Genotypes to Temperature," Plant Cell and Environment, Vol. 25, No. 12, 2002, pp. 1651-1661. doi:10.1046/j.1365-3040.2002.00943.x

[32] V. G. Kakani, et al., "Differences in in vitro Pollen Germination and Pollen Tube Growth of Cotton Cultivars in Response to High Temperature," Annals of Botany, Vol. 96, No. 1, 2005, pp. 59-67. doi:10.1093/aob/mci149

[33] S. K. Singh, et al., "Assessment of Cold and Heat Tolerance of Winter-Grown Canola (Brassica napus L.) Cultivars by Pollen-Based Parameters," Journal of Agronomy and Crop Science, Vol. 194, No. 3, 2008, pp. 225-236. doi:10.1111/j.1439-037X.2008.00309.x

[34] Z. X. Shen, et al., "Stratification in Switchgrass Seeds is Reversed and Hastened by Drying," Crop Science, Vol. 41, No. 5, 2001, pp. 1546-1551. doi:10.2135/cropsci2001.4151546x

[35] Systat Software Inc., "SigmaPlot 10.0-User's Guide," Point Richmond, 2006.

[36] SAS Institute Inc., "SAS/STAT User's Guide, Version 9.1.3.” SAS Institute Inc., Cary, 2004.

[37] D. J. Schimpf, S. D. Flint and I. G. Palmblad, "Representation of Germination Curves with the Logistic Function," Annals of Botany, Vol. 41, No. 6, 1977, pp. 1357-1360.

[38] B. A. Roundy and S. H. Biedenbender, "Germination of Warm-Season Grasses under Constant and Dynamic Temperatures," Journal of Range Management, Vol. 49, No. 5, 1996, pp. 425-431. doi:10.2307/4002924

[39] D. G. Sabo and R. M. Forest, "Germination Requirements of 19 Species of Arid Land Plants," Rocky Mountain 
Forest and Range Experiment Station, Forest Service, US Department of Agriculture, 1979.

[40] I. C Madakadze, et al., "Variation in Base Temperatures for Germination in Warm Season Grasses," Seed Science and Technology, Vol. 29, No. 1, 2001, pp. 31-38.

[41] R. Probert, "The Role of Temperature in the Regulation of Seed Dormancy and Germination," In: M. Fenner, Ed., The Ecology of Regeneration in Plant Communities, CABI Publishing, Wallingford, 2000, pp. 261-292. doi:10.1079/9780851994321.0261

[42] J. Garcia-Huidobro, J. L. Monteith and G. R. Squire, "Time, Temperature and Germination of Pearl Millet (Pennisetum Typhoides S. \& H.) I. Constant Temperature," Journal of Experimental Botany, Vol. 33, No. 2, 1982, pp. 288-296. doi: $10.1093 / \mathrm{jxb} / 33.2 .288$

[43] R. L. Benech-ArNold, et al., "Temperature Effects on Dormancy Release and Germination Rate in Sorghum halepense (L.) Pers. Seeds: A Quantitative Analysis," Weed Research, Vol. 30, No. 2, 1990, pp. 81 - 89.

[44] S. P. Hardegree, "Predicting Germination Response to Temperature. I. Cardinal-Temperature Models and Subpopulation-Specific Regression," Annals of Botany, Vol. 97, No. 6, 2006, pp. 1115-1125. doi:10.1093/aob/mcl071

[45] M. Lopez, et al., "The Effect of Temperature and Water Stress on Laboratory Germination of Eucalyptus Globulus Labill. Seeds of Different Sizes," Annals of Forest Science, Vol. 57, No. 3, 2000, pp. 245-250. doi:10.1051/forest:2000115

[46] K. R. Reddy and V. G. Kakani, "Screening Capsicum
Species of Different Origins for High Temperature Tolerance by in Vitro Pollen Germination and Pollen Tube Length," Scientia Horticulturae, Vol. 112, No. 2, 2007, pp. 130-135. doi:10.1016/j.scienta.2006.12.014

[47] Y. A. El-Kassaby, et al., "Seed Germination: Mathematical Representation and Parameters Extraction," Forest Science, Vol. 54, No. 2, 2008, pp. 220-227.

[48] L. Copeland and M. B. McDonald, "Principles of Seed Science and Technology," 4th Edtion, Springer, Berlin, 2001.

[49] M. D. Casler and A. R. Boe, "Cultivar X Environment Interactions in Switchgrass," Crop Science, Vol. 43, No. 6, 2003, pp. 2226-2233. doi:10.2135/cropsci2003.2226

[50] M. D. Casler, et al., "Latitudinal Adaptation of Switchgrass Populations," Crop Science, Vol. 44, No. 1, 2004, pp. 293-303.

[51] A. Orozco-Segovia, et al., "A Mathematical Model that Uses Gaussian Distribution to Analyze the Germination of Manfreda brachystachya (Agavaceae) in a Thermogradient," Physiologia Plantarum, Vol. 98, No. 3, 1996, pp. 431-438. doi:10.1111/j.1399-3054.1996.tb05696.x

[52] L. E. Moser and K. P. Vogel, "Switchgrass, Big Bluestem and Indiangrass," In: R. F. Barnes, D. A. Miller and C. J. Nelson, Eds., An Introduction to Grassland Agriculture, Iowa State University Press, Ames, 1995, pp. 409-420.

[53] R. Mitchell and L. Moser, "Developmental Morphology and Tiller Dynamics of Warm-Season Grass Swards," In: Anderson, Ed., CSSA, Madison, 2000, pp. 49-66. 